Article

\title{
The Association Between Health Conditions, Consciousness, Involvement, and Knowledge and Dietary Supplement Intake among University Students in South Korea
}

\author{
Jinkyung Choi \\ Department of Foodservice Management, Woosong University, Daejeon 34606, Korea; choi3728@wsu.ac.kr; \\ Tel.: +82-42-630-9453
}

Received: 16 August 2019; Accepted: 12 October 2019; Published: 21 October 2019

\begin{abstract}
Dietary supplements (DSs) are typically used by the elderly in a population, but younger age groups are increasingly purchasing these products. In consideration of this issue, the present study investigated the DS-related behaviors and general lifestyles of university students in South Korea. The health conditions, consciousness, involvement, and knowledge, as well as the future behavioral intentions, of DS users and non-users were determined and compared. A survey was administered to the respondents, and measurements were adapted and rephrased to suit the Korean context. Results showed that although the behaviors of DS users and non-users were characterized by similar patterns, significant differences in health involvement and future purchase were found between these groups. Health involvement influenced DSs buying intentions in the future, but no significant differences in the other variables were found. The findings suggested that university students take DSs regardless of their expectations about their efficacy and that their knowledge does not affect their intention to purchase such products.
\end{abstract}

Keywords: dietary supplements; health involvement; consciousness; health condition; health behaviors; knowledge

\section{Introduction}

Increased life expectancy encourages individuals to lead healthy lives, or perhaps healthy lifestyles allow individuals to have extended life expectancy. People have shown interest in how to pursue a wholesome manner of living and accordingly engage in exercise and consume healthful food, including dietary supplements (DSs) [1]. These products are used by an average of $50 \%$ of adolescent populations in developed countries, with consumption in the US and the UK being especially high [2]. Approximately $54 \%$ of American adults use DSs such as multivitamins and minerals [3].

In the Korean context, about $42 \%$ of adults have taken a DS at least once in their lifetime, as indicated in the results of the Korean National Health and Nutrition Examination Survey in 2015 (KNHANES) [4]. The market for DSs has rapidly increased since 2009, reaching a size of US\$1792 million in 2013 [5]. Vitamin or mineral products are the most frequently consumed supplements in the country [6]. In 2015, the total healthy eating index (HEI) score for Koreans was 57 points [7]. Similar to the Korean HEI score, the total HEI score for Americans was 53.5 points between 2007-2008 [7]. The Korean HEI indicated that although Koreans had a high intake of vegetables, protein, and carbohydrates, their diet was low in sodium and whole grains. Moreover, according to the 2017 Korean National Health and Nutrition Examination Survey (KNHANES), the 19-29 age group had the highest percentage of malnutrition compared with other age groups [8]. From 2016-2017, Korean people's intake of fat, sodium, vitamin $\mathrm{A}$, and vitamin $\mathrm{C}$ decreased by more than $5 \%$ [8]. 
DSs are used by many adolescents [9], such as college students, who are transitioning between adolescence and adult life and still have dietary habits from high school. Such usage is prompted by adjustments to university life, in which behaviors and decisions are less regulated than those in high school life. This transition to university life may therefore result in important changes in dietary choices [10] and dietary patterns [11,12]. Dietary patterns have been strongly associated with DS use [11,13], which is compelled most strongly among college students by the desire to promote general health and increase energy [13]. Patterns of DS consumption showed that about two-thirds of surveyed college students regularly use these products in U.S. [13]. College students in particular take DSs in order to relieve stress and enhance their health as a result of self-decision making and unbalanced dietary habits [5]. However, dependency on DSs may build unhelpful dietary habits for the rest of their lives [5]. In Korea, 36.1\% of individuals aged 19 to 29 years consume DSs-a proportion less than that accounted for by other age groups but more than that of people aged 10 to 18 years in 2015 [4]. DSs user adults responded $27.2 \%$ for men and $40.2 \%$ of women take DS for longer than two weeks during a year [14]. DSs are recommended to consume on a daily basis however this recommendation has not been received well by consumers in somehow. Note, however, that among these groups, college students engage in healthy behaviors such as physical activities, nutritious diet, quality sleep, or stress management to a lesser extent [15]. Once established, lifetime dietary habits may strongly influence the rest of the individual's dietary style. Individuals in this age group develop and build their own food choices. To a lesser extent, family involvement and the surrounding environment affect their dietary habits, which are in the finalizing steps in the process of building up whole lifetime dietary habits. Increased fast food consumption and eating out causes chronic diseases.

Behaviors related to DS intake differ from those associated with the consumption of food. Typically, food is considered a low-involvement product [16], whereas DSs require high involvement given the accompanying extra health benefits that go beyond those offered by food options [17]. Involvement refers to the degree of interest and consideration that an individual devotes to a subject [18]. Involvement behaviors are related to health or dietary options; specifically, one's consideration of health issues, such as variety in healthy meals, nutritional value, and meals that support personal dietary plans, is relevant to the decision to opt for healthy dining [19]. The additional health advantages presented by DS consumption should be attributed in part to the involvement that such usage entails [17]. This argument is supported by a study wherein the level of consumer involvement in the purchase of organic food products was found related to the intention of the customers to purchase such commodities [20].

Individuals become more health conscious as they are increasingly concerned about their well-being and quality of life. Research suggested that health-conscious individuals tend to more strongly espouse a prevention-oriented attitude than do those who are less health conscious. A study that measured the impact of health consciousness on consumer attitudes toward DSs found that these products are effective [21]. Health consciousness factors in proactive behaviors to improve or maintain health [22]. Individuals modify the manner by which they conduct themselves with help from positive stimuli or motivation; negative stimuli may cause behaviors that deviate from healthy choices and thus impede favorable outcomes [23]. Health consciousness may thus be a key determinant of DS consumption and the search for related information, which is abundantly available from a variety of media sources; the problem is that such information is often contradictory and confusing [13].

The judgment of whether health information exerts positive or negative effects requires knowledge. Knowledge regarding healthy ways to eat, for example, is essential in choosing what to consume [24,25]. Nevertheless, the effects of knowledge on food choices are a controversial issue [12,26]. In the case of college students, for instance, although they understand that consuming fast food can cause diseases, their knowledge about such matter is not a factor that influences their consumption choices [12,27]. The food-related behaviors of these young adults are considerably affected primarily by taste, convenience, and cost, with healthiness being last on this list [28-30]. Students spend a substantial amount of time on campus, where the environment that surrounds sustenance, such as 
available food, in terms of variety, price, and convenience may tremendously affect how they behave with respect to food consumption. On the basis of the discussions above, this study investigated the DS-related behaviors and general lifestyles of university students in South Korea. To this end, the health conditions, consciousness, involvement, and knowledge, as well as the future behavioral intentions, of DS users and non-users were ascertained and compared.

\section{Materials and Methods}

\subsection{Participants}

This analytical cross-sectional study recruited university students in South Korea, excluding those who were undergoing medical treatment for health problems. Before the survey, the study questionnaire was approved by the institutional review board (1041549-190709-SB-77) at Woosong University. After the selected respondents expressed agreement to participate in the research, a survey was administered to them. A total of 310 questionnaires were distributed, and 289 were returned. After careful screening, four questionnaires were further eliminated because these were completed by students undergoing medical treatment. Responses which most questions were answered by respondents were entered into a final sample to analysis. A final sample of 285 questionnaires were obtained for analyses. On DS experience, 179 respondents (63.5\%) had experience, while 103 (36.5\%) had not taken DSs previously. Of the DS-experienced respondents, 89 (49.7\%) were taking DSs currently and $90(50.3 \%)$ were not taking DSs.

The sample size appropriate for this study was determined via the $G^{*}$ Power program [31], which uses a $p<0.05$, a power of $95 \%$, an effect size of 0.15 , and four independent variables as components of multiple regression analysis. The calculated size was 129 respondents. The conducted two-tailed $t$-test indicated that a sample size of 54 participants is required on the basis of an effect size of 0.5 and a power of 95 , whereas chi-square statistics estimated this requirement at 220 respondents. The consideration of a $10 \%$ dropout rate yielded a required sample of 242 participants, which was the size adopted in this study.

\subsection{Measurements}

A self-administered questionnaire was used in data collection, which commenced in July 2019. The instrument contains DSs usage information, general health conditions, perceptions towards health behaviors, nutritional knowledge, and demographics. Questions asking DSs usage were excerpted from [32]. The questionnaire also consists of four health-related statements to be rated on a five-point Likert scale (1: not very good, 5: very good), which were also adapted from previous research [32,33]. The four questions that focus on health conditions were based on [17], and an additional four queries into health consciousness were obtained from [17] and Involvement seems to be dynamic, exhibiting characteristics that are specific to the issue of interest in this study. Hence, this research measured involvement on the basis of health information search behaviors. Four questions on this matter were taken from [17]. Questions on future purchase intent was adapted from [32]. All the questions were asked to rate some of the statements on a five-point Likert scale (1: strongly disagree, 5: strongly agree).

To measure individual knowledge, five questions were excerpted from previous studies [34]. Knowledge was measured using five questions, with a correct answer coded as 1 and an incorrect response coded as 0 . The correct responses were added up per respondent then divided by the number of questions, which was 5 . Therefore, the mean values were calculated. 
Body mass index was calculated on the basis of self-reported height $(\mathrm{cm})$ and weight $(\mathrm{kg})$ and were categorized as follows: below $18.5=$ low weight, 18.5 to $22.9=$ normal weight, 23 to $24.9=$ overweight, and $25=$ obese.

The respondents were asked questions regarding DS consumption. Responses of "yes" and "no" to the question of whether one has ever taken DSs were coded as 1 and 0 , respectively. The respondents with DS consumption experience were queried as to (1) whether they were currently taking DSs, (2) whether they were experiencing any side effects, (3) what their preferences are in purchasing DSs, (4) what products they have consumed, and (5) what their reasons are for taking DSs. The demographic characteristics of the participants were also obtained.

\subsection{Statistical Analyses}

The data were analyzed using the Statistical Package for the Social Sciences version 25.0 (IBM, Chicago, IL, USA). Descriptive statistics were used to illustrate the respondents' demographic characteristics and experience with DSs. Cronbach's alpha analysis was run on three independent variables (health condition, consciousness, involvement) to test the validity of the constructs. Independent $t$-tests were performed to ascertain the differences in health-related behaviors between DS users and non-users. A multiple regression was conducted to probe into the effects of health-related behaviors and knowledge on DS purchase.

\section{Results}

\subsection{Demographics}

The demographic characteristics of the respondents are shown in Table 1. More than half of the respondents were female (57.5\%) and single (98\%). The sample was composed mostly of sophomores $(40.8 \%)$, followed by freshmen $(30.3 \%)$, juniors $(17.3 \%)$, and seniors $(11.6 \%)$. The majority of the respondents were aged $20(28.4 \%)$ and $21(28.8 \%)$ years. About $54 \%$ lived on their own, and $37 \%$ resided with their parents. Out of the participants, approximately $30 \%$ were on a diet; most of them $(41.2 \%)$ had neutral opinions regarding their body image, whereas $38.7 \%$ expressed dissatisfaction with such attribute. Only $7 \%$ were satisfied with how their bodies look. The majority of the respondents $(61.2 \%)$ were of normal weight, and $16.4 \%$ were overweight.

College majors, the respondents were divided into those pursuing food- and health-related programs and those studying under non-food and non-health disciplines. All the correct answers of each respondent were summed $(n=275, \mathrm{M}=0.83, \mathrm{SD}=0.79)$. The $t$-tests showed no significant differences in level of knowledge between the food/health and non-food/non-health majors $(t=1.416$, $\mathrm{df}=273, p>0.05)$. 
Table 1. Characteristics of Demographics of the Respondents $(n=285)$.

\begin{tabular}{|c|c|c|c|c|}
\hline \multicolumn{2}{|c|}{ Characteristics } & \multirow{3}{*}{$\begin{array}{c}\begin{array}{c}\text { Frequency } \\
\text { (Valid Percentage) }\end{array} \\
120(42.5) \\
162(57.5)\end{array}$} & \multirow{3}{*}{$\begin{array}{c}\begin{array}{c}\text { DS-Users } \\
\text { (Valid Percentage) }\end{array} \\
75(62.5) \\
104(64.2)\end{array}$} & \multirow{3}{*}{$\begin{array}{c}\begin{array}{c}\text { Non-Ds User } \\
\text { (Valid Percentage) }\end{array} \\
45(37.5) \\
58(35.8)\end{array}$} \\
\hline & Male & & & \\
\hline Gender & Female & & & \\
\hline \multirow{3}{*}{ Marital status } & Married & $5(2)$ & $5(100)$ & $0(0)$ \\
\hline & Single & $275(98)$ & $173(62.9)$ & $102(37.1)$ \\
\hline & Missing & 2 & & \\
\hline \multirow{5}{*}{ Grade } & Freshman & $86(30.3)$ & 56 (65.1) & $30(34.9)$ \\
\hline & Sophomore & $116(40.8)$ & $67(59.3)$ & $46(40.7)$ \\
\hline & Junior & 49 (17.3) & $35(71.4)$ & $14(28.6)$ \\
\hline & Senior & 33 (11.6) & $20(60.6)$ & $13(39.4)$ \\
\hline & Missing & 1 & & \\
\hline \multirow{5}{*}{ Place of residence } & Live in board and lodging & $4(1.4)$ & $4(100)$ & $0(0)$ \\
\hline & Live alone & $154(54.2)$ & $98(64.5)$ & $54(35.5)$ \\
\hline & School dormitory & $21(7.4)$ & $13(61.9)$ & $8(38.1)$ \\
\hline & Live with parents & $105(37.0)$ & $64(61.5)$ & $40(38.5)$ \\
\hline & Missing & 1 & & \\
\hline \multirow{2}{*}{ Major } & Food or health related & $181(63.5)$ & $119(66.1)$ & $61(33.9)$ \\
\hline & $\begin{array}{l}\text { Non-food or non-health } \\
\text { related }\end{array}$ & $104(36.5)$ & $60(58.8)$ & $42(41.2)$ \\
\hline \multirow{3}{*}{ Are you on a diet? } & Yes & $83(29.2)$ & $59(71.1)$ & $24(28.9)$ \\
\hline & No & $201(70.8)$ & $120(60.6)$ & $78(39.4)$ \\
\hline & Missing & 1 & & \\
\hline \multirow{7}{*}{$\begin{array}{l}\text { Are you satisfied with } \\
\text { your body figure? }\end{array}$} & Not very satisfied & 33 (11.6) & $20(60.6)$ & $13(39.4)$ \\
\hline & Not satisfied & $110(38.7)$ & $74(67.9)$ & $35(32.1)$ \\
\hline & So-so & 117 (41.2) & $73(63.5)$ & $42(36.5)$ \\
\hline & Satisfied & $20(7.0)$ & $11(55.0)$ & $9(45.0)$ \\
\hline & Very satisfied & $4(1.4)$ & $1(25.0)$ & $3(75.0)$ \\
\hline & Missing & 1 & & \\
\hline & Below18.5 & $21(8.4)$ & $13(61.0)$ & $8(38.1)$ \\
\hline \multirow{4}{*}{ BMI } & $18.5 \sim 22.9$ & $153(61.2)$ & 93 (61.6) & $58(38.4)$ \\
\hline & $23 \sim 24.9$ & $41(16.4)$ & $26(63.4)$ & 15 (36.6) \\
\hline & 25 and above & $35(14.0)$ & $23(65.7)$ & $12(34.3)$ \\
\hline & Missing & 35 & & \\
\hline
\end{tabular}

\subsection{DSs Intake Behaviours}

Table 2 presents the results of the descriptive analyses of experience with DS. More than half of the respondents $(63.5 \%)$ have taken DSs in their lifetime, whereas $36.5 \%$ have never consumed such products. Of those who have taken DSs, almost half (49.7\%) were taking DSs at the time the study was being conducted. The students stated that they were taking DSs because these were recommended by their families (45.1\%) and because they wanted to promote general health (34.7\%). Some of the respondents had no reason driving their consumption (5.8\%).

The participants typically checked nutritional information on packaging $(48 \%)$ and acquired information from others $(28.7 \%)$ when deciding on purchasing DSs. About $88 \%$ have not experienced side effects when taking DSs, and only a small number of them encountered problems such as digestion issues $(5.5 \%)$, fast heart beat $(2.5 \%)$, constipation $(2.5 \%)$, and headache $(1.2 \%)$. Multiple responses were derived when the participants were asked about the specific DSs that they have taken. The most commonly consumed supplements were multivitamins $(30.3 \%)$, followed by vitamin $C(17.3 \%)$, probiotics $(15 \%)$, omega-3 products $(11.1 \%)$, eye-care supplements such as lutein $(6.5 \%)$, iron $(5.5 \%)$, protein supplements $(5.5 \%)$, supplements that support diet $(4.9 \%)$, and calcium $(3.9 \%)$. 
Table 2. General Dietary Supplement Consumption Behaviors.

\begin{tabular}{|c|c|c|c|}
\hline Questions & Answers & Frequency & Valid Percentage $(\%)$ \\
\hline \multirow{3}{*}{$\begin{array}{l}\text { Have you ever taken } \\
\text { dietary supplements }\end{array}$} & Yes & 179 & 63.5 \\
\hline & No & 103 & 36.5 \\
\hline & Missing & 3 & \\
\hline \multirow[t]{3}{*}{$\begin{array}{c}\text { Are you taking } \\
\text { dietary supplements }\end{array}$} & Yes & 89 & 49.7 \\
\hline & No & 90 & 50.3 \\
\hline & Missing & 106 & \\
\hline \multirow[t]{8}{*}{$\begin{array}{l}\text { * Reason for taking } \\
\text { dietary supplements }\end{array}$} & Promote general health & 60 & 34.7 \\
\hline & No reasons & 10 & 5.8 \\
\hline & $\begin{array}{l}\text { Recommendations from } \\
\text { medical experts for } \\
\text { general health }\end{array}$ & 3 & 1.7 \\
\hline & $\begin{array}{l}\text { Recommendations } \\
\text { from family }\end{array}$ & 78 & 45.1 \\
\hline & $\begin{array}{l}\text { Because of specific } \\
\text { nutritional health promotion }\end{array}$ & 20 & 11.6 \\
\hline & $\begin{array}{l}\text { Because Friends taking } \\
\text { dietary supplements }\end{array}$ & 1 & 0.6 \\
\hline & Others & 1 & 0.6 \\
\hline & Missing & 6 & \\
\hline \multirow[t]{10}{*}{$\begin{array}{l}\text { *Considerations when } \\
\text { select dietary supplements }\end{array}$} & Price & 8 & 4.7 \\
\hline & Brand & 24 & 14 \\
\hline & $\begin{array}{l}\text { Nutritional information } \\
\text { on package }\end{array}$ & 82 & 48 \\
\hline & Quantity & 5 & 2.9 \\
\hline & $\begin{array}{l}\text { Recommendations } \\
\text { from others }\end{array}$ & 49 & 28.7 \\
\hline & Advertisement & 3 & 1.8 \\
\hline & Missing & 8 & \\
\hline & Problems with digestions & 9 & 5.5 \\
\hline & Hives & 0 & 0 \\
\hline & Fast heart beating & 4 & 2.5 \\
\hline \multirow[t]{8}{*}{ * Symptoms of side-effect } & headache & 2 & 1.2 \\
\hline & constipation & 4 & 2.5 \\
\hline & Fallen hair & 1 & 0.6 \\
\hline & Kidney problems & 0 & 0 \\
\hline & Inappetence & 0 & 0 \\
\hline & others & 0 & 0 \\
\hline & $\begin{array}{c}\text { No experience with side } \\
\text { effect }\end{array}$ & 143 & 87.7 \\
\hline & Missing & 16 & \\
\hline
\end{tabular}

* Questions adopted from Sung and Choi [32]. 


\subsection{Assessment of Health Conditions, Involvement and Knowledge}

Four constructs, namely health conditions, health consciousness, health involvement, and future behavioral intention were used to investigate consumers' perception and behavior towards DSs. Three constructs, namely, health conditions (Cronbach's alpha $=0.839)$, health consciousness (Cronbach's alpha $=0.675)$, and health involvement (Cronbach's alpha $=0.875)$, satisfied the validity criteria for measurement. Generally, the respondents exhibited a neutral stance as regards their health conditions $(M=3.16, S D=0.864)$, physical strength $(M=2.90, S D=0.896)$, psychological conditions $(\mathrm{M}=3.20, \mathrm{SD}=0.838)$, and ability to take care of themselves $(\mathrm{M}=3.35, \mathrm{SD}=0.861)$. Similar patterns were found for health consciousness.

The health conditions, health consciousness, health involvement, and future behaviors of the DS users and non-users were compared using independent $t$-tests (Table 3). Each of the constructs exhibited high validity as indices, and the results showed significant differences between the groups in terms of health involvement $(p<0.001)$ and future behavioral intention (i.e., purchase) $(p<0.001)$. However, no such dissimilarities were found with respect to health conditions and health consciousness. The DS users engaged more frequently in information searches than did the non-users, and the former also exhibited an intention to purchase DSs in the future.

Table 3. Comparisons of DS users and non-users of health conditions, consciousness, involvement, and future behavioral intention toward DS.

\begin{tabular}{|c|c|c|c|c|}
\hline Specification of Features & Mean \pm SD & $\begin{array}{l}\text { DS Users } \\
(n=179)\end{array}$ & $\begin{array}{l}\text { Non-DS User } \\
\quad(n=103)\end{array}$ & $t$-Value \\
\hline \multicolumn{5}{|l|}{$\begin{array}{l}\text { Health conditions (Cronbach's } \\
\text { alpha }=0.839)\end{array}$} \\
\hline General health condition & $3.16 \pm 0.864$ & $3.13 \pm 0.844$ & $3.19 \pm 0.886$ & -0.565 \\
\hline General physical strength & $2.90 \pm 0.896$ & $2.91+0.891$ & $2.86+0.886$ & 0.372 \\
\hline Psychological health condition & $3.20 \pm 0.838$ & $3.18+0.822$ & $3.22+0.851$ & -0.432 \\
\hline Ability to take care of yourself & $3.35 \pm 0.861$ & $3.35+0.816$ & $3.34+0.924$ & 0.062 \\
\hline \multicolumn{5}{|l|}{$\begin{array}{c}\text { Health consciousness } \\
\text { (Cronbach's alpha }=0.675)\end{array}$} \\
\hline $\begin{array}{l}\text { Try to prevent health problems } \\
\text { before I feel any symptoms }\end{array}$ & $3.23 \pm 0.878$ & $3.27+0.826$ & $3.17+0.971$ & 0.997 \\
\hline $\begin{array}{l}\text { Concerned about health hazards } \\
\text { and try to prevent problems }\end{array}$ & $3.31 \pm 0.857$ & $3.37+0.828$ & $3.18+0.905$ & 1.792 \\
\hline $\begin{array}{l}\text { Not worried health problems } \\
\text { unless I have any problems }{ }^{\text {a }}\end{array}$ & $2.94 \pm 0.850$ & $3.02+0.804$ & $3.13+0.925$ & -1.041 \\
\hline $\begin{array}{l}\text { Do not take any actions before I } \\
\text { have health problems }{ }^{\text {a }}\end{array}$ & $3.00 \pm 0.866$ & $2.98+0.841$ & $3.06+0.916$ & -0.750 \\
\hline \multicolumn{5}{|l|}{$\begin{array}{l}\text { Involvement (Cronbach's } \\
\text { alpha }=0.875)\end{array}$} \\
\hline $\begin{array}{l}\text { Pay attention to information } \\
\text { regarding DS }\end{array}$ & $2.65 \pm 1.049$ & $2.96+0.993$ & $2.14+0.929$ & $6.827^{* * *}$ \\
\hline $\begin{array}{l}\text { Carefully read nutritional } \\
\text { information on DS package }\end{array}$ & $2.75 \pm 1.083$ & $3.04+1.043$ & $2.25+0.957$ & $6.327^{* * *}$ \\
\hline $\begin{array}{l}\text { Spend time on reading } \\
\text { information regarding } \\
\text { nutritional benefits of DS }\end{array}$ & $2.39 \pm 1.027$ & $2.64+1.063$ & $1.96+0.803$ & $5.642 * * *$ \\
\hline $\begin{array}{l}\text { Read or search for information } \\
\text { regarding health or nutrition }\end{array}$ & $2.36 \pm 1.079$ & $2.58+1.113$ & $2.00+0.918$ & $4.467^{* * *}$ \\
\hline \multicolumn{5}{|l|}{ Future behavioral intention } \\
\hline I will purchase DS in the future & $2.78 \pm 1.081$ & $3.15+0.989$ & $2.16+0.916$ & $8.311^{* * *}$ \\
\hline
\end{tabular}


The correlations among the four constructs are shown in Table 4. A multiple regression was run to ascertain which health-related behaviors affected the intention to purchase DSs ( $F=46.456$, Adj. $\left.R^{2}=0.40, R^{2}=0.406, p<0.001\right)$. The findings showed that health involvement highly affected future DS purchase $(\mathrm{B}=0.756, \mathrm{SE}=0.629, t=12.721, p<0.001)$, whereas health conditions, health consciousness, and knowledge exerted no effects (Table 5).

Table 4. Relationship between health conditions, consciousness, involvement and future behavioral intention.

\begin{tabular}{ccccc}
\hline Constructs & Health Conditions & Consciousness & Involvement & Future Purchase Intention \\
\hline Health conditions & 1 & $0.290^{* *}$ & $0.194^{* *}$ & 0.106 \\
Consciousness & & 1 & $0.274^{* *}$ & $0.218^{* *}$ \\
Involvement & & & 1 & $0.647^{* *}$ \\
Future purchase intention & & & 1 \\
\hline
\end{tabular}

Table 5. Multiple regression results of behavioral intentions.

\begin{tabular}{cccc}
\hline Predictors & B & $S E$ & $T$ \\
\hline Constant & 0.743 & & $2.336^{*}$ \\
Health conditions & -0.053 & 0.075 & -0.704 \\
Health consciousness & 0.092 & 0.052 & 1.029 \\
Health involvement & 0.756 & 0.629 & $12.721^{* * *}$ \\
Knowledge & -0.006 & -0.004 & -0.094 \\
\cline { 2 - 4 } Note: $\mathrm{F}=46.456^{* * *}, \mathrm{R}^{2}=0.406$, Adjusted $\mathrm{R}^{2}=0.400 ;{ }^{*} p<0.05,{ }^{* * *} p<0.001$.
\end{tabular}

All questions asked on 5-point Likert scale (1: very disagreed, 5: very agreed).

\section{Discussion}

This study found that more than half of respondents have taken DSs, and out of these groups, almost half were taking the aforementioned supplements during the course of the research. This result is similar to the outcome of the KNHANES, which indicated that about $42 \%$ of Korean adults have taken a DS at least once in their life [5]. Interestingly, the most important driver of DS consumption is recommendation from family members. College students' behaviors, such as valuing their peers' opinions, were in line with adolescent behaviors. A previous study found that most college students who took DSs were usually recommended to by family and friends [32]. This study also found similar outcomes. University students are still in the transition stage between adolescence and adulthood and may therefore continue to need extra care from their families. Adolescents are a most vulnerable and easily misinformed population [9], who are targeted by the DS industry [35]. Suggestions from friends also considerably influence the health behaviors of university students [32], who tend to emulate their peers. DS consumption is likewise prompted by the desire to promote general health. The transition from high school to college may result in alterations to dietary behaviors because of dramatic changes in surrounding environments [36-38]. To compensate for lifestyle adaptations, college students may consume DSs to maintain overall well-being [5].

The current work found that nutritional information on product packaging was the most important factor for the consideration of DS purchase. Consumers search for information when they make decisions $[39,40]$ because of the many choices and products that are available to them [41]. An intriguing finding in this research is that although the respondents' knowledge levels were low, they still carefully examined nutritional information on packaging, suggesting that some information can be misleading or some other reasons for consumers. Abundant information on DS products may confuse consumers, especially those who have low knowledge of these commodities. Many previous studies confirmed that knowledge level and health behaviors are irrelevant to consumers' decision to purchase products [42]; 
that is, purchase is based on perceptions rather than objective evidence [1,43]. Hence, education that cultivates adequate knowledge about DSs is needed [43].

Recommendations from others accounted for the second most influential factor for DS consumption for the same reasons discussed in regard to family and peer influence. The most commonly consumed DSs were multivitamins, consistent with the findings of another study [6]. Meanwhile DS users and non-users significantly differed in terms of DS intake, but no such difference was found in connection with other health-related behaviors.

DSs can be beneficial to one's health; if an individual is driven to take these products out of concern for his/her well-being, then such behavior may motivate other healthful habits, such as regular exercise. However, no differences were found between DS users and non-users. The relationship between stress and food intake is a well-known phenomenon. Food intake increases and shifts toward unhealthy choices when people are exposed to stressful conditions [44]. Concerns have been raised regarding the possibility that DSs will encourage individuals to eat less healthy food or pursue unhealthy lifestyles [13]. DS users may rely solely on supplements and neglect other health behaviors that may bring about positive health outcomes.

The prevalence of DS consumption has been attributed to health conditions and health consciousness. This study postulated that health consciousness significantly affects DS consumption, but general health conditions and health consciousness were viewed in a neutral manner by both the DS users and non-users. These individuals were highly confident about their health and physical strength. Given that DSs are dispensed without the need for a prescription and are available to all individuals who may have different health conditions, the benefits of such products may be minimal, and their efficacy remains controversial [6]. Therefore, although the DS users may have been aware of the potentially weak efficacy of DSs, they also held positive perceptions of the benefits of consuming these supplements. This positivity might have stemmed from advertisements that deliver highly persuasive messages in a fiercely competitive DS market [43]. The result can also be attributed to the DS users understanding that supplement consumption helps them keep pace with the demands of campus life [12], which is known to present easy access to rapidly available snacks, regardless of the health condition and consciousness of students.

Given that involvement is difficult to measure [17], information search behaviors were used instead. These behaviors were significantly more prevalent among the DS users than non-users. Involvement is related to certain manners of conduct because DS purchase requires considerable cognitive effort [17], in contrast to food purchase [17,20]. As previously mentioned, the DS users and non-users exhibited no difference in terms of health conditions and consciousness. Thus, individuals in need of DSs look for information and are finally led to purchase these supplements.

\section{Conclusions}

This study investigated DS usage behaviors among university students in South Korea. Abundant studies have examined the manner by which university students conduct themselves in connection with their diets, but few have been directed specifically toward shedding light on the effects of health conditions, consciousness, and involvement on DS intake among South Korean students. The present study found that surveyed college students believed that they were healthy [9] and only moderately conscious of their general health. Moreover, their health consciousness was unrelated to their information searching behaviors regarding their health. This may be the result of their lack of nutritional knowledge or due to strong social bonds with their peer group. Additionally, the results indicated that their DS consumption was highly influenced by recommendations from family and friends. Since they were not knowledgeable of nutrition, they would review the package's nutritional information when deciding whether to make a purchase-this behavior suggests that they may purchase DSs that they do not need. Furthermore, certain statements on the packages may motivate and persuade them to make unnecessary purchases. Hence, to avoid reckless DS intake, proper educational interventions are necessary. 
For the DS industry, fierce marketing is necessary for them to survive in the market. However, persuasive but vague statements should be prevented for these products to be effectively used in the next stage of university life for DS users. These students will enter the workplace and might need DSs more than ever for their health as they grow older. Achieving longevity in the DS market necessitates the formulation of policies regarding supplements.

The limitations of this research should be noted for future studies. First, this study was conducted in a campus in South Korea; thus, different university students around the world should be involved in future research. Second, campus lifestyles should also be investigated to examine the DS consumption and dietary habits of students. Third, to assess which areas require nutritional education, actual nutritional intake and the consumption of DSs should be measured. Finally, the specific ingredients of DSs and related behaviors should be examined to draw implications for the industry and the well-being of consumers taking DSs. The results of the present research may add to the DS literature as university students take these products, regardless of their health conditions or consciousness. Moreover, their knowledge levels do not affect their intention to buy DSs, thus raising the risk of misuse among the population. Appropriate educational intervention is necessary to enable university students to avoid adverse effects from DSs.

Funding: This research is based support of 2019 Woosong University Academic Research Funding.

Conflicts of Interest: The author declares no conflict of interest.

\section{References}

1. Homer, P.M.; Mukherjee, S. The impact of dietary supplement form and dosage on perceived efficacy. J. Consum. Mark. 2018, 35, 228-238. [CrossRef]

2. Guallar, E.; Stranges, S.; Mulrow, C.; Appel, L.J.; Miller Iii, E.R. Enough Is Enough: Stop Wasting Money on Vitamin and Mineral Supplements. Ann. Intern. Med. 2013, 159, 850-852. [CrossRef] [PubMed]

3. Bailey, R.L.; Gahche, J.J.; Lentino, C.V.; Dwyer, J.T.; Engel, J.S.; Thomas, P.R.; Betz, J.M.; Sempos, C.T.; Picciano, M.F. Dietary supplement use in the United States, 2003-2006. J. Nutr. 2011, 141, 261-266. [CrossRef] [PubMed]

4. Korea Center for Disease Control and Prevention. Korea Health Statistics 2015: Korea National Health and Nutrition Examination Survey; KCDC: Cheongju-si, Korea, 2015. Available online: https://knhanes.cdc.go.kr/ knhanes/sub04/sub04_03.do?classType=7 (accessed on 15 October 2019).

5. Choi, J.-H.; Je, Y. Use of vitamin and mineral supplements and related variables among university students in Seoul. J. Nutr. Health 2015, 48, 352-363. [CrossRef]

6. Kim, M.; Lee, Y.; Park, K. Vitamin and Mineral Supplement Use among Korean Adults: Baseline Data from the Trace Element Study of Korean Adults in Yeungnam Area. Nutrients 2018, 10, 50. [CrossRef]

7. Korea Center for Disease Control and Prevention. Healthy Eating Indix for Koreans was 59 Points; KCDC: Chengju-si, Korea, 2015. Available online: https://www.cdc.go.kr/board.es?mid=a20501000000\&bid=0015\& act $=$ view\&list_no $=65847$ (accessed on 15 October 2019).

8. Korea Center for Disease Control and Prevention. Korean Health Statistics 2017: Korea National Health and Nutrition Examination Survey (KNHANES 7-2); KCDC: Cheongju-si, Korea, 2017. Available online: https://knhanes.cdc.go.kr/knhanes/sub04/sub04_03.do?classType=7 (accessed on 15 October 2019).

9. Rahi, A. "Supplementing" the DSHEA: Congress Must Invest the FDA with Greater Regulatory Authority over Nutraceutical Manufacturers by Amending the Dietary Supplement Health and Education Act. Calif. Law Rev. 2010, 98, 439.

10. Brown, O.N.; O'Connor, L.E.; Savaiano, D. Mobile MyPlate: A Pilot Study Using Text Messaging to Provide Nutrition Education and Promote Better Dietary Choices in College Students. J. Am. Coll. Health 2014, 62, 320-327. [CrossRef]

11. Borsari, B.; Carey, K.B. Peer influences on college drinking: A review of the research. J. Subst. Abus. 2001, 13, 391-424. [CrossRef]

12. Abraham, S.; Noriega, B.R.; Shin, J.Y. College Students Eating Habits and Knowledge of Nutritional Requirements. J. Nutr. Hum. Health 2018, 2, 13-17. [CrossRef] 
13. Lieberman, H.R.; Marriott, B.P.; Williams, C.; Judelson, D.A.; Glickman, E.L.; Geiselman, P.J.; Dotson, L.; Mahoney, C.R. Patterns of dietary supplement use among college students. Clin. Nutr. 2015, 34, 976-985. [CrossRef]

14. Park, H.A. Top 10 dietary supplements of korean adults from the 4 th Korea national health and nutrition examination survey. Korean J. Fam. Med. 2011, 32, 263-266. [CrossRef] [PubMed]

15. Miller, T.; Chandler, L.; Mouttapa, M.M.F.E. A Needs Assessment, Development, and Formative Evaluation of a Health Promotion Smartphone Application for College Students. Am. J. Health Educ. 2015, 46, 207-215. [CrossRef]

16. Zaichkowsky, J.L. The emotional affect of product involvement. Adv. Consum. Res. 1987, 14, 32-35.

17. Kamrath, C.; Bidkar, S.; Bröring, S. Is food involvement in purchasing decisions always low? A consumer study from Germany. Pharma Nutr. 2019, 9. [CrossRef]

18. Mittal, B. Measuring Purchase-Decision Involvement. Psychol. Mark. 1989, 6, 147-162. [CrossRef]

19. Choi, J.; Zhao, J. Consumers' behaviors when eating out: Does eating out change consumers' intention to eat healthily? Br. Food J. 2014. [CrossRef]

20. Teng, C.C.; Lu, C.H. Organic food consumption in Taiwan: Motives, involvement, and purchase intention under the moderating role of uncertainty. Appetite 2016, 105, 95-105. [CrossRef]

21. Royne, M.B.; Fox, A.K.; Deitz, G.D.; Gibson, T. The Effects of Health Consciousness and Familiarity with DTCA on Perceptions of Dietary Supplements. J. Consum. Aff. 2014, 48, 515-534. [CrossRef]

22. Michaelidou, N.; Hassan, L.M. Modeling the factors affecting rural consumers' purchase of organic and free-range produce: A case study of consumers' from the Island of Arran in Scotland, UK. Food Policy 2010, 35, 130-139. [CrossRef]

23. Elliot, A.J.; Church, M.A. A Hierarchical Model of Approach and Avoidance Achievement Motivation. J. Personal. Soc. Psychol. 1997, 72, 218-232. [CrossRef]

24. Driskell, M.M.; Dyment, S.; Mauriello, L.; Castle, P.; Sherman, K. Relationships among multiple behaviors for childhood and adolescent obesity prevention. Prev. Med. 2008, 46, 209-215. [CrossRef] [PubMed]

25. Josiam, B.; Foster, C. Nutritional information on restaurant menus. Int. J. Contemp. Hosp. Manag. 2009, 21, 876-891. [CrossRef]

26. Choi, J.; Choi, A. Perceptions of food labelling about allergens in food products in South Korea. Br. Food J. 2016, 118, 2842. [CrossRef]

27. Stockton, S.; Baker, D. College Students' Perceptions of Fast Food Restaurant Menu Items on Health. Am. J. Health Educ. 2013, 44, 74-80. [CrossRef]

28. Boek, S.; Bianco-Simeral, S.; Chan, K.; Goto, K. Gender and race are significant determinants of students' food choices on a college campus. J. Nutr. Educ. Behav. 2012, 44, 372-378. [CrossRef] [PubMed]

29. Hebden, L.; Chan, H.N.; Louie, J.C.; Rangan, A.; Allman-Farinelli, M. You are what you choose to eat: Factors influencing young adults' food selection behaviour. J. Hum. Nutr. Diet. 2015, 28, 401-408. [CrossRef]

30. Tam, R.; Yassa, B.; Parker, H.; O'Connor, H.; Allman-Farinelli, M. University students' on-campus food purchasing behaviors, preferences, and opinions on food availability. Nutrition 2017, 37, 7-13. [CrossRef]

31. Faul, F.; Erdfelder, E.; Buchner, A.; Lang, A.G. Statistical power analyses using G*Power 3.1: Tests for correlation and regression analyses. Behav. Res. Methods 2009, 41, 149-160. [CrossRef]

32. Sung, Y.; Choi, J. Protein Supplement Usage Among Male University Students: Comparisons Between Current and Previous Users. J. Am. Coll. Nutr. 2018, 37, 127-132. [CrossRef]

33. Min, K.-H. A Study on the Eating Habits and Healthy Eating Behaviors of the University Students in Jeonbuk Area. Korean J. Food Cook. Sci. 2013, 29, 399-406. [CrossRef]

34. Andrews, J.C.; Netemeyer, R.G.; Burton, S. Consumer Generalization of Nutrient Content Claims in Advertising. J. Mark. 1998, 62, 62-75. [CrossRef]

35. Perko, M.; Bartee, R.T.; Dunn, M.S.; Qi, W.M.; Eddy, J. Giving new meaning to the term 'taking one for the team': Influences on the use/non-use of dietary supplements among adolescent athletes. Am. J. Health Stud. 2000, 16, 99.

36. Crombie, A.P.; Ilich, J.Z.; Dutton, G.R.; Panton, L.B.; Abood, D.A. The freshman weight gain phenomenon revisited. Nutr. Rev. 2009, 67, 83-94. [CrossRef] [PubMed]

37. Wengreen, H.J.; Moncur, C. Change in diet, physical activity, and body weight among young-adults during the transition from high school to college. Nutr. J. 2009, 8, 32. [CrossRef] [PubMed] 
38. Fedewa, M.V.; Das, B.M.; Evans, E.M.; Dishman, R.K. Change in weight and adiposity in college students: A systematic review and meta-analysis. Am. J. Prev. Med. 2014, 47, 641-652. [CrossRef] [PubMed]

39. Kevin Lane, K.; Richard, S. Effects of Quality and Quantity of Information on Decision Effectiveness. J. Consum. Res. 1987, 14, 200.

40. Redelmeier, D.A.; Shafir, E.; Aujla, P.S. The Beguiling Pursuit of More Information. Med Decis. Mak. 2001, 21, 376. [CrossRef]

41. Lauren, A.L.; Mauricio, R.D. The Inherent Reward of Choice. Psychol. Sci. 2011, 22, 1310. [CrossRef]

42. Axon, D.R.; Vanova, J.; Edel, C.; Slack, M. Dietary Supplement Use, Knowledge, and Perceptions Among Student Pharmacists. Am. J. Pharm. Educ. 2017, 81,1-12. [CrossRef]

43. Karbownik, M.S.; Paul, E.; Nowicka, M.; Nowicka, Z.; Kowalczyk, R.P.; Kowalczyk, E.; Pietras, T. Knowledge about dietary supplements and trust in advertising them: Development and validation of the questionnaires and preliminary results of the association between the constructs. PLoS ONE 2019, 14, e218398. [CrossRef]

44. O'Connor, D.B.; Jones, F.; Conner, M.; McMillan, B.; Ferguson, E. Effects of daily hassles and eating style on eating behavior. Health Psychol. 2008, 27, S20-S31. [CrossRef] [PubMed]

(C) 2019 by the author. Licensee MDPI, Basel, Switzerland. This article is an open access article distributed under the terms and conditions of the Creative Commons Attribution (CC BY) license (http://creativecommons.org/licenses/by/4.0/). 